\title{
ENVIRONMENTAL AGENDA IN PUBLIC ADMINISTRATION: PRIORITY AXES FOR THE SECRETARIAT OF FINANCE IN THE CITY OF MANAUS, BRAZIL
}

\author{
Sandra Farias de Moraes ${ }^{1}$ \\ Secretaria de Finanças de Manaus \\ Zenóbia Menezes de Brito ${ }^{2}$ \\ Instituto Federal de Educação, Ciência e Tecnologia do Amazonas \\ Antônio Venâncio Castelo Branco ${ }^{3}$ \\ Instituto Federal de Educação, Ciência e Tecnologia do Amazonas \\ Elizany Monteiro Moreira ${ }^{4}$ \\ Universidade Federal do Amazonas \\ Ana Lúcia Soares Machado ${ }^{5}$ \\ Secretaria de Finanças de Manaus \\ Pedro Antônio de Melo ${ }^{6}$ \\ Universidade Federal de Santa Catarina \\ Márison Luiz Soares ${ }^{7}$ \\ Universidade Federal do Espírito Santo \\ Daniel Nascimento-e-Silva ${ }^{8}$ \\ Instituto Federal de Educação, Ciência e Tecnologia do Amazonas
}

\begin{abstract}
The Environmental Agenda in Public Administration (A3P) emerges as an essential tool for the modernization of Brazilian public management. This study aimed to identify the priority axes and actions capable of structuring an A3P for the Municipal Finance Secretariat (SEMEF) of the municipality of Manaus. A qualitative study was carried out, whose respondents are SEMEF managers, consulted based on interview script, whose data were organized with word processors, analyzed with content analysis tools, and interpreted based on the similarities and differences in the respondents' positions. The results showed that the rational use of
\end{abstract}

\footnotetext{
${ }^{1}$ Especialista em Administração Pública, Faculdade Educacional da Lapa (FAEL). Servidora pública, Secretaria de Finanças de Manaus, Amazonas, Brazil. Avenida Brasil, 2971, Compensa, 69036-110, Manaus, Amazonas, Brazil. http://orcid.org/0000-00021055-2664. E-mail: sfdemoraes@mail.com.

${ }^{2}$ Mestra em Engenharia de Produção, Universidade Federal do Amazonas (UFAM). Técnica Administrativa no Instituto Federal de Educação, Ciência e Tecnologia do Amazonas (IFAM), Manaus, Amazonas, Brazil. Avenida Cosme Ferreira, 8.045, São José Operário, 69083-000, Manaus, Amazonas, Brazil. http://orcid.org/0000-0002-4496-4018. E-mail: zenobia_1@hotmail.com

${ }^{3}$ Mestre em Engenharia de Produção, Universidade Federal do Amazonas (UFAM). Professor do Instituto Federal de Educação, Ciência e Tecnologia do Amazonas, Manaus, Amazonas, Brazil. Rua Ferreira Pena, 1.109, Centro, 69025-010, Manaus, Amazonas, Brazil. http://orcid.org/0000-0001-8463-0269. E-mail: venancio@ifam.edu.br.

${ }^{4}$ Mestra em Ciências Ambientais, Universidade Federal do Amazonas (UFAM). Pesquisadora autônoma. Rua Acari, 59, Conjunto Atílio Andreaza, Japiim, 69077-620 Manaus, Amazonas, Brazil. http://orcid.org/0000-0002-0305-7323. E-mail: elizanymonteiro30@gmail.com.

${ }^{5}$ Doutora em Desenvolvimento Sustentável, Universidade de Brasília (UnB). Professora do Instituto Federal de Educação, Ciência e Tecnologia do Amazonas (IFAM), Manaus, Amazonas, Brazil. Avenida Governador Danilo de Matos Areosa, 1672, Distrito Industrial, 69075-350 Manaus, Amazonas, Brazil. http://orcid.org/0000-0002-5977-2377. E-mail: ana.machado@ifam.edu.br.

${ }^{6}$ Doutor em Engenharia de Produção, Universidade Federal de Santa Catarina (UFSC). Professor da Universidade Federal de Santa Catarina (UFSC), Florianópolis, Santa Catarina, Brazil. Rua Eng. Agronômico Andrei Cristian Ferreira, s/n, Trindade, 88040-900 Florianópolis, Santa Catarina, Brazil. http://orcid.org/0000-0001-7607-4303. E-mail: pedro.inpeau@gmail.com.

7 Doutor em Engenharia de Produção, Universidade Federal de Santa Catarina (UFSC). Professor da Universidade Federal do Espírito Santo (UFES), Vitória, Espírito Santo, Brazil. Avenida Fernando Ferrari, 514, Goiabeiras, 29075-910 Vitória, Espírito Santo, Brazil. http://orcid.org/0000-0003-3269-9365. E-mail: marison16@hotmail.com.

${ }^{8}$ Doutor em Engenharia de Produção, Universidade Federal de Santa Catarina (UFSC). Professor do Instituto Federal de Educação, Ciência e Tecnologia do Amazonas (IFAM), Manaus, Amazonas, Brazil. Avenida Governador Danilo de Matos Areosa, 1672, Distrito Industrial, 69075-350 Manaus, Amazonas, Brazil. http://orcid.org/0000-0001-9770-575X. E-mail: danielnss@mail.com.
} 
resources, adequate waste management, sustainable construction, and quality of life at work were the four axes considered priorities to structure the A3P. The conclusion shows that the axes, initiatives, and results found are consistent with the philosophy and practice intended by $\mathrm{A} 3 \mathrm{P}$.

Keywords: A3P, Public management, Environmental management, Sustainability, Rational use of resources, Proper waste management, Quality of life at work.

\section{Agenda Ambiental na Administração Pública: Eixos e ações prioritárias para a Secretaria de Finanças da cidade de Manaus, Brasil.}

\section{Resumo}

A Agenda Ambiental na Administração Pública (A3P) surge como uma ferramenta essencial para a modernização da gestão pública brasileira. Este estudo teve como objetivo identificar os eixos e ações prioritários capazes de estruturar um A3P para a Secretaria Municipal de Fazenda (SEMEF) do município de Manaus. Foi realizado um estudo qualitativo, cujos respondentes foram os gestores da SEMEF, consultados a partir de roteiro de entrevista, cujos dados foram organizados em processadores de texto, analisados com ferramentas de análise de conteúdo e interpretados a partir das semelhanças e diferenças nas posições dos respondentes. Os resultados mostraram que o uso racional de recursos, a gestão adequada de resíduos, a construção sustentável e a qualidade de vida no trabalho foram os quatro eixos considerados prioritários para estruturar o A3P. A conclusão mostra que os eixos, iniciativas e resultados encontrados estão de acordo com a filosofia e prática pretendida pela A3P.

Palavras-chave: A3P, Gestão pública, Gestão ambiental, Sustentabilidade, Uso racional de recursos, Gestão adequada de resíduos, Qualidade de vida no trabalho.

\section{Agenda Ambiental en Administración Pública: Ejes prioritarios y acciones para la Secretaría de Hacienda de la ciudad de Manaus, Brasil.}

\section{Resumen}

La Agenda Ambiental en la Administración Pública (A3P) surge como una herramienta esencial para la modernización de la gestión pública brasileña. Este estudio tuvo como objetivo identificar los ejes y acciones prioritarios capaces de estructurar un A3P para la Secretaría de Hacienda Municipal (SEMEF) del municipio de Manaus. Se realizó un estudio cualitativo, cuyos encuestados son gerentes de la SEMEF, consultados en base a guión de entrevista, cuyos datos fueron organizados con procesadores de texto, analizados con herramientas de análisis de contenido e interpretados en base a las similitudes y diferencias en las posiciones de los encuestados. Los resultados mostraron que el uso racional de los recursos, la adecuada gestión de residuos, la construcción sustentable y la calidad de vida en el trabajo fueron los cuatro ejes considerados prioritarios para estructurar el A3P. La conclusión muestra que los ejes, iniciativas y resultados encontrados son consistentes con la filosofía y práctica que pretende A3P.

Palabras clave: A3P, Gestión pública, Gestión medioambiental, Sostenibilidad, Uso racional de los recursos, Gestión adecuada de residuos, Calidad de vida en el trabajo.

\section{INTRODUCTION}

The search for effectiveness has led organizations to new standards of functioning and commitment. It is effectively understood as the need to be, at the same time, efficient and effective, which implies, therefore, the challenge of producing as much as possible (efficiency) so that the intended objectives can be achieved (effectiveness) continuously. This new mentality underlies the practical possibility of continually incorporating new knowledge into organizational activities.

And one of the dimensions of these new standards links the organization's activities to maintaining environmental balance. It implies making the organization work without compromising the environmental resources placed at its disposal or not. It is not because electricity, for example, is being paid for by the organization that its employees may waste it, first because it implies

Brazilian Journal of Policy and Development | ISSN: 2675-102X | v. xx, n. xx, p. xx-xx, Jan. - Mai, 2021 
operating costs and, just as importantly, it compromises the water stock of fossil fuel that produces it. It is a new mentality that opens up in organizations.

For this mentality to be part of the Brazilian public administration, some action courses have been rehearsed. One of them is the Environmental Agenda in Public Administration (A3P, of the concept in Portuguese), the study's object. This initiative has attracted more and more followers, mainly due to the ease of understanding that its axes allow each server. Thus, this study aimed to identify the main axes and actions of a possible environmental plan for the Municipal Finance Secretariat of the city of Manaus so that the environmental mentality can be implanted there.

This article is organized into five parts, the first being this introduction. The second shows the intricacies of $\mathrm{A} 3 \mathrm{P}$, reconstituting its state of the art. The third describes the methodological path that led to the results of the investigation. The fourth part presents the results and discusses their developments and theoretical-empirical implications. The last brings some final considerations to the discoveries made.

\section{THE ENVIRONMENTAL AGENDA IN PUBLIC ADMINISTRATION}

A3P is a program (Santos, 2017). This program seeks to bring to the public administration, at the federal, state, municipal level, and in the three branches, a sustainability policy through socioenvironmental responsibility principles, thus becoming a government environmental management milestone. Sustainability encompasses the environmental scope and the social and economic ones, which must act together and permeate all government actions to generate a better quality of life for society.

According to Almeida, Scatena, and Luz (2017), public institutions should also be concerned with environmental issues, so A3P was created to motivate this initiative in the public sphere. On the other hand, Camargo (2018) highlights three essential aspects of the A3P concept: objective, means, and public managers' administrative actions. A3P is a program that aims to encourage public administration to adopt the principles and criteria of social and environmental management in their routine activities. However, public managers must adopt some procedures, such as the rational use of public goods, adequate waste management, sustainable bidding and promotion, awareness, and quality of life at work. These procedures tend to result in saving natural resources and reducing institutional spending. To saving institutional expenses and natural resources, it is necessary to adopt specific actions, ranging from the rational use of public goods, through the proper management of waste and the adoption of sustainable bidding, to the awareness and training of servers and managers.

Likewise, Viana (2017) sees A3P as a program. But it suggests numerous actions that will help the public administration to incorporate the principles of socio-environmental responsibility. These actions include changes in the form of investments, purchases, and contracting of services by the government. They also cover civil servants' awareness and training, preparing them for adequate management of the natural resources used and the waste generated, leading to improved quality of life in the work environment.

Pereira (2017) explains that A3P is an initiative of the Brazilian Ministry of the Environment (MMA), whose main objective is to make public organizations adopt social and environmental responsibility actions. These signals the concern and care that the government is devoting to various environmental issues. Thus, managers' challenge at the various levels of public agencies is to promote information and a change in the cultural vision about sustainability in the public service. 
A3P can therefore be understood as a reaction of MMA about serious environmental issues, aiming to encourage public agencies in Brazil, adopt in their activities, internal and external, actions in social and environmental responsibility (Freitas, 2017; Rosset, 2017). Among the environmental disasters caused in the name of progress, global warming, increased pollution, scarcity of resources, environmental degradation, water contamination, deforestation, and so many other damages, affecting and threatening ecosystems and, by extension, the society that depends on them. But mainly due to the deadly exploratory form of modern man. In this sense, public agencies are mobilized in general and seek ways to minimize the environmental impacts that threaten us by adopting an organizational management model focused on environmental and socio-economic sustainability based on A3P, developed by MMA.

In recent years, it is observed that the environmental issue has become a trend in the strategic planning of organizations. Especially public ones, which are rethinking their way of working with less effort, fewer expenses, and less disposal, cause less impact on the environment. There is, then, an absolute consensus in the scientific literature regarding the concept of $\mathrm{A} 3 \mathrm{P}$, defined as a program (Santos et al., 2017; Camargo, 2018; Viana, 2017; Freitas, 2017; Rosset, 2017). Pereira (2017) considers it just an MMA initiative, while Almeida, Scatena, and Luz (2017) interpret it as one of the measures to face environmental issues in public agencies.

The scientific literature agrees that A3P seeks to integrate socioenvironmental principles in the routine activities of public administration. However, studies by Viana (2017), Pereira (2017), and Freitas (2017) refer to actions of socio-environmental responsibility to be adopted in the activities of public agencies. Viana (2017) further identifies that these actions include the change in investments that involve purchases and contracting of services by the government, the awareness and training of civil servants, and the proper management of the natural resources used and the waste generated. The consequence intended by this new form of management is to improve the quality of life in the workplace in a more sustainable way.

For this study, A3P is considered a program created by the MMA that seeks to encourage the implementation of socio-environmental management principles within the scope of public administration. What led to this program's creation was the public service's need to follow the economic trends and society's new patterns that consider sustainability. The reversal of the threats of socio-environmental impacts is a challenge to be pursued, mainly due to the incredible power of purchase of goods and services by the public agencies. Thus, if there are interest and commitment, public agencies can influence the wide range of suppliers and partners in sustainable practices, thus playing a fundamental role in implementing public sustainability policies directed by A3P.

According to Santos et al. (2017), A3P is composed of five thematic axes. These axes were defined based on 5R: Rethink, Reduce, Reuse, Recycle and Refuse. Likewise, the study by Almeida, Scatena, and Luz (2017) highlights five thematic axes, namely: 1) rational use of resources; 2) waste management; 3) quality of life in the work environment; 4) public awareness and training and 5) sustainable bidding. According to these authors, A3P has become a benchmark for public administration sustainability, including UNESCO's recognition of its relevance and the positive results.

However, Camargo (2018), regarding the practice of sustainable actions, mentions six axes that guide public administration: 1) rational use of natural resources and public goods; 2) proper management of the waste generated; 3 ) quality of life in the work environment; 4) public awareness and training; 5) sustainable bids and 6) sustainable constructions, reforms, and expansions. 
Public agencies realized the need and relevance that sustainable development practices generate and can serve as an example in an environmentally responsible administration to reduce negative socioenvironmental impacts. Likewise, Viana's (2017) study also presents five main thematic axes that guide the practice of A3P: rational use of natural resources and public goods, adequate management of waste generated, quality of life in the work environment, awareness, and training of employees and sustainable bidding.

Pereira (2017) highlights sustainable bidding as one of the axes of A3P and sustainable actions that public agencies must adopt. Among the set of sustainable actions, this research relates: changes in investments, purchases and contracting of services by the government, raising awareness and training of civil servants, adequate management of the natural resources used and waste generated, and promoting quality of life work environment.

For Freitas (2017), A3P is based on five axes: the rational use of natural resources and public goods, adequate management of waste generated, quality of life in the work environment, awareness and training, and sustainable bidding. Rosset's study (2017) recognizes saving natural resources, reducing institutional spending through the rational use of public goods, waste management, sustainable bidding, and promoting quality of life in the work environment as thematic axes.

For Cavalcante (2012), A3P's actions include the change in investments, purchases and contracting of services by the government, raising awareness and training employees, proper management of the natural resources used and waste generated, and the promotion of improved quality of life in the environment of work. This set of actions seeks to sensitize public managers to socio-environmental issues, review production and consumption patterns, and promote the saving of natural resources and reduce institutional expenses. The thematic axes are materialized in the form of challenges that organizations face, as shown in Table 1.

Table 1. Thematic axes and challenges of A3P

\begin{tabular}{|l|l|}
\hline Thematic Axis & Challenge \\
\hline Rational use of resources & $\begin{array}{l}\text { Make the most of all available means to achieve the } \\
\text { necessary ends }\end{array}$ \\
\hline Proper waste management & $\begin{array}{l}\text { Provide the appropriate destination of waste in a } \\
\text { planned way }\end{array}$ \\
\hline Quality of life at work & Keeping employees fully healthy in the workplace \\
\hline Awareness and training of civil servants & $\begin{array}{l}\text { Make the servers realize that it is necessary always to } \\
\text { develop themselves }\end{array}$ \\
\hline Sustainable bids & Purchasing supplies in a sustainable way \\
\hline Sustainable buildings & $\begin{array}{l}\text { Perform construction and alterations rationally and } \\
\text { efficiently }\end{array}$ \\
\hline
\end{tabular}

Source: Prepared by the authors.

Monteiro and Camelo (2015) also refer to five guiding thematic axes: proper waste management, sustainable bidding, quality of life in the work environment, awareness and training of employees, and rational use of resources. For public bodies interested in implementing sustainable management, the authors define the necessary steps to implement the Agenda. Initially, the institution must sign the Term of Adhesion and create an A3P Commission, involving employees who are representatives of the interested institution's various areas. The next step is to diagnose the situation, identify the critical points, waste, and assess the environmental impacts to elaborate integrated planning. This planning is what will define the projects and activities to be developed, 
starting with the diagnosis. The following phases involve training managers, providing physical and material resources for the most urgent actions, identifying flaws and points for improvement, monitoring and evaluating the entire environmental process, and systematic assessment with a redesign to promote continuous improvement.

In addition to the five thematic axes, Camargo (2018) refers to a sixth, which was included in 2015, covering civil engineering, architecture, and urbanism. It refers to implementing criteria for sustainable constructions, reforms, and extensions. It considers that civil construction consumes a significant amount of natural resources and generates various types of waste. It also provides quality of life with the buildings built, which characterizes the relationship between construction and the environment when seeking to minimize environmental impacts. Sustainable construction is defined as a holistic process that aspires to restore and maintain harmony between the environments, natural and built, and the creation of settlements that affirm human dignity and encourage economic equity. It is observed that this definition covers the three aspects of sustainability: social, economic, and environmental.

\section{RESEARCH METHODOLOGY}

According to the guidelines of Nascimento-e-Silva (2012; 2020a; 2020b) e Silva et al. (2020), the type of research that guided the field activities was qualitative for two reasons. The first is related to the SEMEF managers' vision where the data will be collected; that is, it is a local group, which requires the use of an instrument that allows a thorough understanding of the phenomenon under study. The second is related to the need to understand several aspects that other instruments would not detect. That can only be perceived when conducting data collection, as is the case with respondents' positions and worldviews.

Even though they are a collective creation, environmental agendas require a relatively longtime horizon to be created, implemented, and monitored for their results. With this investigation, what was intended was to know the priority thematic axes for the management body and which analytical categories or environmental initiatives should be part of each priority axis. The search for an understanding of why each axis and category were considered priorities and how they could be implemented perfected the investigation's scope.

\section{Guiding Questions}

Three guiding questions were selected to guide the fieldwork: 1) What are the two priority thematic axes for creating an institution's environmental Agenda? 2) What would be the two environmental initiatives that each axis should contemplate? 3) What results could be obtained if these initiatives are implemented?

\section{Participants}

This research encompassed three questions addressed to the secretary and the five sub secretaries of Management, Revenue, Treasury, Information Technology, and Budget and Projects (SEMEF). The participants in this study are the strategic management body of SEMEF in Manaus, capital of the State of Amazonas. This choice was recommended because it is recommended that

Brazilian Journal of Policy and Development | ISSN: 2675-102X | v. xx, n. xx, p. xx-xx, Jan. - Mai, 2021 
institutional leaders be the prominent supporters for environmental actions, which guarantees both greater motivational appeal of the staff and demonstrates the organizational determination to change the mentality and operational postures. Only four SEMEF sub secretaries responded to the survey.

The Subsecretary of Management is a Production Engineer, has over 20 years in the strategic and organizational management area of large, medium, and small companies; including the coordination of certifications and audits in Quality Management System, Environment, Occupational Safety and Health, Food Safety and Social Responsibility.

The Subsecretary of Revenue has 29 years as City Hall fiscal auditor of municipal taxes. He has already collaborated in various functions: tax coordinator, deputy director, taxation director, twice inspection director, service director, president of the fiscal resource's administrative council, director, and sub secretary of SEMEF.

The Undersecretary for Budget and Projects, the agency's career servant, has a degree in Civil Engineering, specializing in Tax Law and Project Management. She developed activities in the areas of public debt, Municipal Budget Execution, and Municipal Planning.

The Information Technology Undersecretary has a degree in Forestry Technology, Wood Industry Modality. He has a postgraduate degree in Web System Development. Postgraduate studies in Project Management. He was director of the ICT Infrastructure area at the Manaus City Hall, working at the Secretariat of Science and Information Technology.

\section{Data collection: instrument, collection strategy, and interpretation of results}

The data were collected through a semi-structured interview script, in which it is known the questions for which we will have to get answers (guiding questions), but we do not know what answers we will get. After being collected, the data were recorded and typed in a word processor, following what was said; that is, no changes were made in words or in the respondents' terms to maintain data fidelity.

All the answers to each guiding question were grouped, with the help of a synthesizer board, to be analyzed. This process was carried out following the content analysis rules, seeking to know the differences and similarities of the responses obtained. According to the survey respondents' point of view, the results' interpretation was based on the similarities between the responses, which meant the search for the degree of consensus among respondents about the items containing each thematic axis of the environmental Agenda.

\section{RESULTS AND DISCUSSION}

Three guiding questions were selected to guide the fieldwork: 1) What are the two priority thematic axes for creating an institution's environmental Agenda? 2) What would be the two environmental initiatives that each axis should contemplate? 3) What results could be obtained if these initiatives are implemented?

\section{Environmental Initiatives to implement A3P}

The Subsecretary for Budgets and Projects (SUBOP) suggested putting into practice work to reduce, reuse, and recycle (3R) natural resources and public goods without neglecting non- 
generation aspects based on the reuse of materials instead of simple disposal for disposal. She also suggested the implementation of a municipal program for the rational use of water throughout the municipality, including the entire school network and health units, with practical attitudes and educational murals, due to the high cost of water in public areas, in addition to numerous waste of natural resources, thus strengthening environmental awareness. Finally, she also proposed the implementation of recycling of materials in all buildings owned by the municipality.

As environmental initiatives, the Under-Secretary of Revenue (SUBREC) highlighted the adoption of digital processes at SEMEF, resulting in a significant reduction in paper, which is gradually being extended to all municipal departments. He suggested an appropriate treatment and disposal of the waste produced to recycle what was possible. Referring to the conscious and rational use of non-polluting energies, he considered solar energy in buildings owned by the city hall as an example but said he depended on public policies.

The Subsecretariat of Management (SUBGES) reported on its project to implement the eight Criteria for Excellence in Public Management. The Public Interest and Citizenship criterion stands out, which deals strongly with management practices related to socio-environmental responsibility. Within this improvement process, SUBGES identified the need to implement a process for managing the secretariat's environmental impact. It included implementing a selective collection process and proper disposal of waste to reduce its environmental impact.

The Subsecretariat of Information Technology (SUBTI) informed that SEMEF has already been carrying out several actions that conform to the objectives of A3P. However, he pointed out in the scope of SUBTI that the Data Center project was conceived aiming at the best use of the lighting and quick and efficient dissipation of the heat coming from the machines contained in that environment. He said that the tenders made from the basic projects prepared by SUBTI consider the concepts of sustainability. The acquired equipment has hyper-convergence technology, which allows for more processing capacity and scalability with less physical space and the consequent saving of electric energy.

Table 1. Environmental initiatives suggested by the respondents

\begin{tabular}{|l|l|}
\hline Secretariat & Environmental Initiatives \\
\hline Budgets and Projects & $\begin{array}{l}\text { Rational use of water in the municipality } \\
\text { Strengthen environmental awareness } \\
\text { Implement material recycling in all buildings }\end{array}$ \\
\hline Revenue & $\begin{array}{l}\text { Formulation of public policies } \\
\text { Awareness of servers } \\
\text { Use of virtual processes } \\
\text { Rational use of water and energy }\end{array}$ \\
\hline Management & $\begin{array}{l}\text { Know the environmental impact of the secretariat } \\
\text { Elaboration of material to raise public awareness } \\
\text { Implementation of selective collection } \\
\text { Proper disposal of waste }\end{array}$ \\
\hline Information Technology & $\begin{array}{l}\text { Dissemination at all levels of the organ } \\
\text { Server training } \\
\text { Follow-up methodology } \\
\text { Deployment of virtual processes }\end{array}$ \\
\hline
\end{tabular}

Source: data collected by the authors.

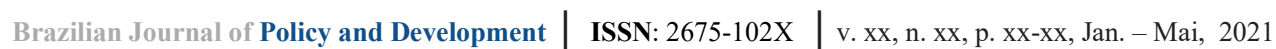


It is observed that the implementation of virtual processes was mentioned by two of the four sub secretaries, as the paper savings resulting from this initiative are relevant. Also standard is the concern with the rational use of water and energy and selective collection, which requires an awareness of servers.

Each initiative has its peculiarity. Any State policy that is to be implemented needs to be disclosed at all levels of the organization. The purpose is for everyone to know, to know, to know what will be done. These initiatives must be followed by a good training program for each employee, highlighting their role in achieving the general and specific objectives. Also, creating action plans specific to each initiative will help reach each goal and, finally, adopt a robust monitoring methodology to avoid deviations during the execution of the action plans that hinder the goals' achievement.

SUBOP also reported on some steps necessary for the implementation of environmental initiatives, such as: creating an A3P management commission in each secretariat, free of charge; perform a diagnosis of each institution; elaborating projects, and proposing activities; such objectives necessarily need to be specific and the goals measurable monthly for constant evaluation; promote mobilization and awareness; carry out the evaluation and monitoring of actions.

\subsection{A3P Thematic Axes}

About the six thematic axes of A3P, SUBOP highlighted the axes of sustainable construction and rational use of public resources and goods. The first axis suggested for new buildings in their buildings, better use of space and that promote conservation and rational use of water, energy efficiency, the use of some products with environmental certification, and the choice of materials and technologies low environmental impact.

SUBREC referred to the axes rational use of resources and proper waste management. He highlighted the adoption of digital processes at SEMEF, which resulted in a significant reduction in paper. The conscious and rational use of non-polluting energies considered solar energy in buildings owned by the city hall as an example but depended on public policies.

SUBGES highlighted the rational use of resources and proper waste management, suggesting implementing a selective collection process and proper disposal of waste to reduce its activities' environmental impact.

SUBTI referred to the rational use of resources and quality of life at work axes. It pointed out that SUBTI's projects already take sustainability into account when they aim to produce more excellent production with the economy, providing a better environment for servers and less environmental aggression.

Chart 2. Thematic axes suggested by the respondents

\begin{tabular}{|l|l|}
\hline Secretariat & Thematic Axis \\
\hline Budgets and Projects & $\begin{array}{l}\text { Rational use of resources } \\
\text { Sustainable buildings }\end{array}$ \\
\hline
\end{tabular}

Brazilian Journal of Policy and Development | ISSN: 2675-102X | v. 3, n. 1, p. 29-43, 2021 


\begin{tabular}{|l|l|}
\hline Recipe & $\begin{array}{l}\text { Rational use of resources } \\
\text { Proper waste management }\end{array}$ \\
\hline Management & $\begin{array}{l}\text { Rational use of resources } \\
\text { Proper waste management }\end{array}$ \\
\hline Information Technology & $\begin{array}{l}\text { Rational use of resources } \\
\text { Quality of life at work }\end{array}$ \\
\hline
\end{tabular}

Source: data collected by the authors.

It is observed that the rational use of resources was the common axis pointed out by the four undersecretaries, which reflects an interest in promoting a change in the culture of waste, in addition to the concern with reducing production costs, especially in the matter of water consumption, light, paper, and disposables. It also means a joint vision of action in SEMEF's new management profile. The overall view is necessary to realize the possible dissonances between the organizational units searching for the acquisition of balance in each one's efforts, facilitating entrepreneurial management action (Miranda \& Silveira, 2010).

The second most cited thematic axis was adequate waste management, demonstrating a concern regarding prevention, reduction, and, when possible, recycling and reuse of solid waste and the proper disposal in the environment of what cannot be recycled. Prevention is a form of anticipatory intervention of possible unpleasant consequences or acquisition of satisfactory results (Teodori, 2018; Sprandel, 2007) and often works as an educational practice (Ribeiro et al., 2019).

According to their areas' specificity, each undersecretary presented suggestions for actions that are already underway or with possibilities for implementation in the short term. Only SUBOP mentioned the sustainable construction axis with the adoption of measures that optimize spaces, promote the economy of natural resources and the quality of life of employees and taxpayers, and minimize negative impacts on the environment. Only SUBTI referred to the quality of life in the work environment axis. These two axes are closely related to promoting the work environment's quality in terms of its physical aspect since it is also linked to non-physical aspects as the perception of justice and labor relations, among others (Azambuja, Kerber \& Kirchhof, 2007; (Lima, Jorge \& Moreira, 2006; Andrade, 2010).

The axes of sustainable bidding and public awareness and training were not suggested by any sub-secretariats consulted. However, SUBTI informed that the tenders made from its basic projects consider sustainability concepts and that the equipment acquired has hyper-convergence technology. These attitudes allow for more processing capacity and scalability with less physical space and consequent energy savings. The tenders represent an effort to horizontalize public institutional policies towards society, represented in its suppliers (Magalhães \& Cestari, 2016), expanding the public sector's decision-making process for these spheres (Tavares, 2005). For that, public servants must be trained to deal with this format of expanded public management. They empower being prepared to consciously deal with new realities by modifying reality (Torres \& Lelis, 2010; Marcondes, Brisola \& Chamon, 2015).

\subsection{Intended Results with A3P}

With the suggested measures, SUBOP expects a radical reduction in the consumption of paper, water, energy, disposable cups, and the use or delivery to recycling at least $90 \%$ of the recyclable 
waste produced by the secretariats. SUBREC, on the other hand, expects results that include a reduction in expenses and material for the secretariat. Also, better use of suitable material and recycling for use than possible. That reflects the lesser aggression to nature with clean energy and less inadequate waste disposal. SUBGES expects to achieve the proper destination of recyclable waste and more significant commitment and awareness of the server to reduce its activities' environmental impact.

Table 3. Results intended by the respondents

\begin{tabular}{|l|l|}
\hline Secretariat & Intended results \\
\hline Budgets and Projects & $\begin{array}{l}\text { Reduction of energy, water, paper, and glass consumption } \\
\text { Reuse of recyclable waste }\end{array}$ \\
\hline Recipe & $\begin{array}{l}\text { Reduction of expenses and material } \\
\text { Better use of material } \\
\text { Less aggression to nature }\end{array}$ \\
\hline Management & $\begin{array}{l}\text { Proper disposal of all waste } \\
\text { More significant commitment and awareness of the server }\end{array}$ \\
\hline Information Technology & Fulfillment of City Hall's mission \\
\hline
\end{tabular}

Source: data collected by the authors.

SUBTI emphasized the fundamental role of SEMEF in carrying out the mission of the Manaus City Hall. This mission is to manage the city by promoting sustainable socio-economic and environmental public policies by strengthening its regional identity, raising the quality of life, and promoting business, as described in the Strategic Planning Manaus 2030 (Ribeiro Neto et al., 2018). For this, SEMEF's performance in raising funds for employment in the main areas, reducing administrative expenses, and improving interaction processes with the taxpayer is essential. This set of measures, which fall within the axes proposed by the A3P program, is expected mainly in the quality of life in employees' work environment and awareness about sustainability and sustainable purchases.

It was found that the current actions of SEMEF are aligned with the initiatives of the Strategic Planning Manaus 2030. The plan has eight axes of excellence. The Strategic Axes of Management Efficiency, Social and Environmental Development, aim to raise the government's standard of municipal management efficiency, raise the population's quality of life, and be a national reference in environmental sustainability. These axes are in tune with A3P's proposals and axes.

Strategic plans are the unfolding of strategic thinking, which is how the public agency will meet the demands of the environment and, in return, is supplied by it. They then explain the results that are intended to be achieved (Antunes, 2019) based on agreements with society in a coalition format (Fernandes, 2019) and that become part of the routine of all members of the government (Moreira, Santiago \& Batista, 2019). The alignment of A3P's initiatives with the strategic plan, therefore, represents its institutionalization.

\subsection{Other initiatives likely to be adopted}

The research showed interest in SEMEF managers' part in the radical reduction of energy, water, paper, cups consumption, the proper disposal for waste, and recycling material. Other 
actions can be implemented within the scope of SEMEF and the initiatives already suggested, according to the four axes of A3P shown in table 4.

Table 4. Initiatives adopted or likely to be adopted

\begin{tabular}{|c|c|}
\hline A3P Thematic Axes & Initiatives \\
\hline $\begin{array}{l}\text { 1. Rational use of goods and } \\
\text { natural resources }\end{array}$ & $\begin{array}{l}\text { 1. Reduction of disposable cups and adoption of mugs or } \\
\text { bottles; } \\
\text { 2. Adoption of LED lamps; } \\
\text { 3. Use of presence sensors for lighting; } \\
\text { 4. Printing documents only in case of need and use on both } \\
\text { sides of the paper; } \\
\text { 5. Use of economical valves for flushing and taps; } \\
\text { 6. Reuse of scratch paper and } \\
\text { 7. Collection of rainwater or air conditioning for reuse. } \\
\text { 8. Digital process (paper expense reduction) adopted }\end{array}$ \\
\hline $\begin{array}{l}\text { 2. Waste management } \\
\text { generated }\end{array}$ & $\begin{array}{l}\text { 1. Adoption of electronic waste collection (cell, cell phone, old } \\
\text { electronic devices); } \\
\text { 2. Adoption of paper collection for recycling; } \\
\text { 3. Adoption of selective and } \\
\text { 4. Adoption of partnership with waste pickers' cooperative }\end{array}$ \\
\hline $\begin{array}{l}\text { 3. Awareness and training of } \\
\text { servers }\end{array}$ & $\begin{array}{l}\text { 1. Promote educational lectures on socio-environmental } \\
\text { issues; } \\
\text { 2. Promote the training of environmental agents to be } \\
\text { multipliers in the agency and } \\
\text { 3. Distribute leaflets or fix posters or banners on sustainability. }\end{array}$ \\
\hline $\begin{array}{l}\text { 4. Quality of life in the work } \\
\text { environment }\end{array}$ & $\begin{array}{l}\text { 1. Offer work gymnastics for servers; } \\
\text { 2. Offer a social worker and nutritional guidance service and } \\
\text { 3. Offer psychological service for cases of addictions and } \\
\text { psycho-emotional disorders (stress, neurosis, phobias, etc.). }\end{array}$ \\
\hline
\end{tabular}

Source: data collected by the authors.

The actions that are possible to be implemented represent the range of those that do not require much motivational effort and convincing to take effect. Unlike the structuring ones, whose intention is to construct an institutional environmental culture, the possible actions of immediate implementation can represent the fastest way to convince because they present the example's strength. With the results obtained by the government's actions, the institutionalizing actions, which expand the actions to all units of the public agency, will gain more strength and vigor, demonstrating that it is worth pursuing the A3P's intentions.

\section{CONCLUSION}

This study showed the main themes and actions of a possible environmental Agenda for the Finance Secretariat of the city of Manaus. The "rational use of resources" was the consensual axis, pointed out by all respondents, to be part of SEMEF's environmental Agenda, followed by the need for "Adequate waste management," pointed out by two respondents, and "Sustainable buildings" and "Quality of life at work," both with a mention. These four axes represent what is considered a

Brazilian Journal of Policy and Development | ISSN: 2675-102X | v. xx, n. xx, p. xx-xx, Jan. - Mai, 2021 
priority so that environmental practices can be installed in the institution and start a path of conformity of mentality and environmental practices.

The environmental initiatives suggested (and many already practiced) by the respondents, which represent the actions that must be planned and carried out so that the axes effectively materialize, involve both the awareness of the institution's social body and the practice of using and taking advantage of the available resources. These resources involve both directly related to the environment: electricity and water and those that relate indirectly, such as efficient financial resources.

Finally, the intended results, which the organization's strategic management has in mind, are a consequence of achieving efficiency in using available resources to guarantee the institutional mission. It means that when natural and financial resources are optimized, nature wins. Less energy and water consumption while reducing its operating cost also mean less need to use natural stocks to produce them), the institution benefits, the community maintains its stocks of natural resources and future generations' existence.

\section{REFERENCES}

Almeida, R., Scatena, L. M., \& Luz, M. S. (2017). 'Percepção ambiental e políticas públicas: dicotomia e desafios no desenvolvimento da cultura de sustentabilidade', Ambiente e Sociedade, 20(1), 43-64.

Andrade, S. M. (2010) Percepção de justiça distributiva no clima organizacional: um estudo sobre organizações brasileiras que buscam se destacar pela qualidade do ambiente de trabalho. Unpublished Master thesis, Universidade de São Paulo, São Paulo, Brazil.

Antunes, C. M. (2019). Informações sobre desempenho orçamentário: estudo comparativo das normas orçamentárias no Brasil e Estados Unidos da América, Revista do Serviço Público, 70(2), 219-238. https://doi.org/10.21874/rsp.v70i2.2919.

Azambuja, E. P., Kerber, N. P., \& Kirchhof, A. L. (2007). A saúde do trabalhador na concepção de acadêmicos de enfermagem, Revista da Escola de Enfermagem da USP, 41(3), 355362. http://dx.doi.org/10.1590/S0080-62342007000300003.

Camargo, L. S. (2018). Práticas socioambientais em uma instituição de ensino superior estadual do Paraná. Unpublished Master thesis, Universidade do Oeste do Paraná, Foz do Iguaçu, Brazil.

Cavalcante, M. L. S. A. (2012). Administração pública e agenda ambiental - A3P: considerações sobre a implementação nos órgãos públicos, Revista Controle: Doutrinas e Artigos, 10(1), 193-216.

Fernandes, A. M. V. (2019). Megaeventos e Turismo no Rio de Janeiro: um olhar sobre o Planejamento Estratégico e a promoção da imagem da cidade, Caderno Virtual de Turismo, 19(1), 1-16. http://dx.doi.org/10.18472/cvt.19n1.2019.1532.

Freitas, E. R. (2017). Os desafios da implementação das compras públicas sustentáveis no IFNMG - Campus Montes Claros. Unpublished Master thesis, Universidade Federal da Bahia, Salvador, Brazil. 
| II ENVIRONMENTAL AGENDA IN PUBLIC ADMINISTRATION: PRIORITY AXES AND FOR THE SECRETARIAT OF FINANCE IN THE CITY OF MANAUS, BRAZIL

Lima, F. E. T., Jorge, M. S. B., \& Moreira, T. M. M. (2006). Humanização hospitalar: satisfação dos profissionais de um hospital pediátrico, Revista Brasileira de Enfermagem, 59(3), 291-296.

Magalhaes, R. P., \& Cestari, L. A. S. (2016). O programa de educação ambiental do estado da Bahia-(PEA-BA) como proposta de horizontalização das relações entre Estado-Sociedade civil', REMEA-Revista Eletrônica do Mestrado em Educação Ambiental, Esp, 159-183. https://doi.org/10.14295/remea.v0i0.5569.

Marcondes, N. A. V., Brisola, E. M. A., \& Chamon, E. M. Q. O. (2015). Busca autônoma por educação permanente e consolidação da identidade profissional crítica, Serviço Social em Revista, 17(2), 187-208.

Miranda, C. M. S., \& Silveira, A. Empreendedorismo corporativo na universidade: o entendimento de gestoras catarinenses. Proceedings of the VI Encontro de Estudos sobre Empreendedorismo e Gestão de Pequenas Empresas, EGEPE, Recife, Brazil.

Monteiro M. O., \& Camelo G. L. P. (2015). Agenda ambiental na administração pública A3P nos campi do IFRN: um olhar a partir dos gestores, Revista Empírica BR, 1(1), 26-42.

Moreira, E. S., Santiago, W. P., \& Batista, I. V. C. (2019). Balanced scorecard: estudo sobre sua utilização como instrumento de gestão na empresa Novo Nordisk no Brasil. ForScience, 7(2). http://dx.doi.org/10.29069/forscience.2019v7n2.e642.

Nascimento-e-Silva, D. (2020a). Manual do método científico-tecnológico. Manaus: DNS Editor.

Nascimento-e-Silva, D. (2020b). Regras básicas para redação acadêmica. Manaus: DNS Editor.

Nascimento-e-Silva, D. (2012). Manual de redação para trabalhos acadêmicos: position papers, ensaios teóricos, artigos científicos e questões discursivas. São Paulo: Atlas.

Pereira, E. R. (2017). Uma Análise da contribuição do setor de patrimônio do jardim botânico do Rio de Janeiro na gestão das compras públicas sustentáveis. Unpublished Master thesis, Universidade Federal Fluminense, Niterói, Brazil.

Ribeiro Neto, A. V. C. et al. (Coords.). (2018). Planejamento Estratégico: Manaus 2030, Prefeitura Municipal de Manaus, Manaus.

Ribeiro, P. et al. (2019). Prevenção nas escolas construindo uma cultura sem drogas, Revista Científica de Iniciación a la Investigación, 4(1), 1-12.

Rosset, A. C. S. (2017). Compras públicas sustentáveis: um estudo dos critérios de sustentabilidade utilizados nas contratações da Empresa Brasileira de Infraestrutura Aeroportuária - Infraero. Unpublished Master thesis, Universidade Federal de Alagoas, Maceió, Brazil.

Santos, F. L. et al. (2017). Análise da adesão à agenda ambiental na administração pública (A3P) pela cidade portal da Amazônia, Revista Eletrônica Gestão \& Sociedade, 11(28), 1583-1610.

Silva, R. O., Ferreira, J. A. O. A., Rivera, J. A., Souza, S. S., \& Nascimento-e-Silva, D. (2020). Definition, elements and stages of elaboration of research protocols. Research, Society and Development, 9(10), e3189108721. http://dx.doi.org/10.33448/rsd-v9i10.8721. 
Sousa E. S., \& Carvalho D. B. (2015). Educação para gestão ambiental: um estudo dos instrumentos propostos pela administração pública federal voltados ao consumo sustentável. Revista Brasileira de Educação Ambiental, 10(2), 283-300.

Sprandel, M. A. (2007). A questão migratória como objeto de reflexão. Caderno de Debates, (2), 35-50.

Tavares, C. M. M. (2005). A interdisciplinaridade como requisito para a formação da enfermeira psiquiátrica na perspectiva da atenção psicossocial. Texto \& Contexto Enfermagem, 14(3), 403-410.

Teodori, R. M. (2018). Prevalência de lombalgia no setor de fisioterapia do município de Cosmópolis-SP e o papel da fisioterapia na sua prevenção e recuperação. Fisioterapia Brasil, 6(2), 113-118. http://dx.doi.org/10.33233/fb.v6i2.1972.

Torres, H. C., \& Lelis, R. B. (2010). Oficinas de formação de profissionais da equipe saúde da família para a gestão do acolhimento com classificação de risco. Ciencia y Enfermería, 16(2), 107113.

Viana, W. M. (2017). Design colaborativo na construção de um projeto para divulgação de bens descartados na Universidade Federal do Rio Grande do Norte. Unpublished Master thesis, Universidade Federal do Rio Grande do Norte, Natal, Brazil.

Submitted: mar.2021.

Approved: mar.2021.

Published: mar.2021. 